\title{
EKSPLORASI VISUAL PASAR TRADISIONAL SEBAGAI PENDUKUNG DALAM PERANCANGAN FILM ANIMASI PENDEK "POTRET"
}

\author{
Muhammad Firdaus \\ School of Design, Universitas Bina Nusantara \\ muhammadfirdaus@binus.ac.id
}

\begin{abstract}
Abstrak
Umumnya pasar ditandai oleh penjual dan pembeli yang saling bertemu. Proses jual beli biasanya melalui proses tawar menawar karena harganya bukan merupakan harga tetap. Pasar tradisional tidak hanya sebagai tempat transaksi untuk menjual dan membeli, namun juga bisa menjadi tempat multifungsi, seperti; interaksi sosial dan fungsi budaya. Seiring perkembangan teknologi, banyak developer membangun beberapa area bisnis modern seperti; mal, ritel, supermarket, hypermart, dan sebagainya. Sehingga, keberadaan pasar tradisional saat ini menjadi tenggelam. Tujuan dari penelitian ini adalah untuk mendapatkan dan mengumpulkan informasi / sumber yang valid guna memproses film animasi pendek yang memanfaatkan pasar tradisional sebagai setting dan fokus utama. Penelitian ini akan menggunakan metode kualitatif dengan wawancara, survei, dan observasi di lokasi. Kesimpulan dari penelitian ini adalah keberadaan pasar tradisional saat ini mulai memprihatinkan. Hal ini dikarenakan umumnya pasar tradisional tidak mengikuti perkembangan zaman dan tidak mengikuti tuntutan pasar. Karena itu, pasar tradisional tidak mampu bersaing dengan pusat perbelanjaan modern. Konsumen yang memutuskan untuk pergi ke pasar tradisional dikarenakan faktor kebiasaan dan jarak tempuhnya.
\end{abstract}

Kata-kata kunci: pasar tradisional, animasi, eksistensi

\begin{abstract}
Generally, market is marked by buyers and sellers who meet each other. The process of buying and selling are usually through the process of bargaining system because the price is not a fixed-price. Traditional market is not only as a place to buy and sell transactions, but also it could be as a multifunctional place, such as; social interaction and cultural functions. As technology development has grown up nowadays, many developers built some modern business area such as; mall, retails, supermarket, hypermart, and so on. So that, the existence of traditional market, nowadays, become function-shift. The purpose of the research is to get and gather the information/valid sources for processing short animation film that use traditional market as a setting and central focus. The research is going to use qualitative methods by interviewings, surveyings, and observation on the location. The conclusion of this study is the existence of traditional markets nowadays are going to be collapsed. It is because the traditional market mostly doesn't keep abreast of the times and not following the demands of market. Therefore, the traditional market is not able to compete with the modern shopping centre. The consumers decide to go to the traditional market because of their self-habit and distance.
\end{abstract}

Keywords: traditional market, animation, existension 


\section{PENDAHULUAN}

Pasar tradisional dalam pelaksanaannya bersifat tradisional dan ditandai dengan pembeli serta penjual yang bertemu secara langsung. Proses jual-beli biasanya melalui proses tawar menawar harga, dan harga yang diberikan untuk suatu barang bukan merupakan harga tetap, dalam arti lain masih dapat ditawar, hal ini sangat berbeda dengan pasar modern. Selain itu, bukan hal yang tidak mungkin jika pasar ini juga berfungsi sebagai tempat berinteraksi yang dipenuhi dengan kehangatan para pengunjungnya.

Ciri khas pasar tradisional adalah adanya tenda-tenda tempat penjual memasarkan dagangannya, serta pembeli yang berjalan hilir mudik untuk memilih dan menawar barang yang akan dibelinya. Pasar ini tidak sekadar sebagai tempat transaksi jual beli, tetapi juga dapat berkembang menjadi lokasi yang multifungsi dan memiliki fungsi sosial dan budaya sehingga akan sangat menarik untuk mengetahui dan memperdalam mulai dari arti, sejarah hingga hal-hal di dalam pasar tradisional itu sendiri. Karena kesederhanaan tersebut, pasar memiliki nilai lokal konten yang tinggi sehingga akan lebih menarik untuk meneliti lebih dalam hal-hal yang ada di pasar tradisional maupun sekitarnya. Sayangnya, nilai lokal pasar tradisional banyak yang kurang diekspos ke animasi.

Industri animasi Indonesia sudah mulai terlihat adanya perberkembangan, hal ini dapat terlihat dari pemanfaatan animasi di media advertising dan filmnya. Animasi dengan set pasar terkadang kita jumpai di animasi-animasi lokal dan tidak sedikit audiens yang tertarik akan hal ini, yang menjadikannya menarik karena pasar adalah salah satu poin local content disana yang membuatnya seakan memberi kesan keseharian diselimuti kehangatan para pengunjungnya contohnya animasi lokal yang terkenal seperti short animation Lakon yang terkenal dengan Transformer bajajnya hingga beberapa episode dalam Series Adit Sopo Jarwo.

Dengan semakin berkembangnya zaman, teknologi akan semakin maju. Hal ini ditandai dengan pembangunan mall dan supermarket yang membuat keberadaan pasar tradisional mulai tergeser. Meskipun begitu, para pengunjung setia pasar tradisional akan tetap ada dan selalu mengisi pasar ini dengan kebutuhan sehari-hari mereka mulai dari sebelum terbit fajar hingga petang menjelang malam.

Atas dasar keunikan inilah penulis mengambil tema pasar tradisional sebagai dasar dalam membuat latar tempat dan suasana dari animasi pendek ini karena masih minimnya pengetahuan masyarakat terhadap keberadaan animasi lokal sehingga tidak banyak masyarakat yang sadar akan beragamnya animasi di Indonesia. Selain itu, diharapkan agar konsep yang ada di dalamnya bisa menginspirasi sekaligus memberi wawasan baru dunia animasi khususnya di Indonesia.

\section{Kajian Literatur}

Animasi

Kata animate berasal dari kata kerja Latin animare, yang berarti "membuat jadi hidup atau mengisi dengan nafas". Pada animasi kita benar-benar bisa merestrukturisasi realitas (Wright 2005:1). Pengertian secara umum, animate memiliki arti "memberi kehidupan kepada" dan termasuk juga live-action (gerakan langsung) pedalangan /pewayangan /permainan boneka semisal Sesame Street serta penggunaan peralatan electromechanical untuk menggerakkan boneka, dinamakan animatronics (Rick Parent, 2010:6). Animasi dapat didefinisikan sebagai suatu proses penciptaan ilusi gerakan pada benda mati dengan cara menyajikan gambar-gambar 
secara berurutan (sekuensial) silih berganti secara cepat (Chong, 2008: 8). Menurut Bordwell (2006:33) menyatakan bahwa film animasi dibuat dari frame per frame. Gambar dapat ditarik langsung pada strip film atau kamera yang memungkinkan dalam memotret gambar per frame nya ataupun model $3 \mathrm{~d}$. Saat ini sebagian besar film animasi dibuat langsung komputer dengan perangkat lunak pencitraan. Pada konteks film, Animasi lebih bersifat imajinatif tanpa ada batasan-batasan realitas, serta dapat mereproduksi ide-ide non-objektif dan fantasi (Prakosa, 2010: 100). Selanjutnya Prakosa (2010: 348) menyebutkan fungsi-fungsi animasi, salah satunya yaitu, animasi dapat membuka tabir yang tidak nyata. Hal-hal abstrak yang sulit digambarkan melalui live shot dapat digambarkan secara mudah dengan animasi.

Animator harus lebih memiliki 'kepekaan gerak' daripada 'hanya' sekedar kemampuan menggambar. Gambar yang bagus akan percuma tanpa didukung kemampuan menghidupkan. Sebagaimana definisi dasar animasi yang berarti: membuat seolah-olah menjadi hidup. Dalam buku Illusion of Life, Ollie Johnston menjelaskan terdapat 12 prinsip animasi yang akan membuat animasi menjadi 'hidup'. Ke-12 prinsip ini meliputi solid drawing (kemampuan menggambar dan kepekaan terhadap anatomi, komposisi, berat, keseimbangan, dan pencahayaan), timing and spacing (gerak percepatan dan perlambatan), squash and stretch (pemberian efek dinamis seperti memuai dan menyusut dalam gerak sehingga benda yang mati dapat seolah hidup), anticipation (ancang -ancang dalam bergerak), slow in and slow out (akselerasi dan deselerasi suatu gerakan), arcs (bentuk gerak lengkung yang dihasilkan dari pergerakan benda sehingga benda tersebut tampak hidup tidak seperti gerakan robot yang patah patah), secondary action (gerakan tambahan untuk memperkuat gerakan utama sehingga nampak lebih realistis), follow through and overlapping action (keadaan dimana suatu benda tetap bergerak sekalipun telah berhenti dan gerakan saling silang ketika bergerak), straight ahead action and pose to pose (cara pengerjaan proses animasi), staging (peletakan karakter sehingga mendukung suasana), appeal (gaya animasi), exaggeration (mendramatisir suatu kejadian secara ekstrim).

Pengertian Pasar Tradisional

Pasar tradisonal adalah tempat berjualan yang tradisional (turun temurun), tempat bertemunya penjual dan pembeli dimana barang-barang yang diperjual belikan tergantung kepada permintaan pembeli (konsumen), harga yang ditetapkan merupakan harga yang disepakati melalui suatu proses tawar menawar, pedagang selaku produsen menawarkan harga sedikit diatas harga standart. Pada umumnya pasar tradisional merupakan tempat penjualan bahanbahan kebutuhan pokok (sembako). Biasanya pasar tradisional beraktivitas dalam batas-batas waktu tertentu, seperti pasar pagi, pasar sore, pasar pekan dan lain sebagainya.

Pasar tradisional biasanya dikelola oleh pemerintah maupun swasta, fasilitas yang tersedia biasanya merupakan bangsal-bangsal, loods-loods, gudang, took-toko, stand-stand/kios-kios, toilet umum pada sekitar pasar tradisional. Pada pasar tradisional proses jual beli terjadi secara manusiawi dan komunikasi dengan nilai-nilai kekeluargaan yang tinggi.

Dalam Peraturan Presiden tentang pembangunan, penataan dan pembinaan pasar tradisional, pusat perbelanjaan dan toko modern memutuskan bahwa: Pasar tradisional adalah pasar yang dibangun dan dikelola oleh pemerintah, Pemerintah 
daerah, Swasta, Badan usaha milik negara dan Badan usaha milik Daerah termasuk kerjasama dengan swasta dengan tempat usaha berupa toko, kios, loods dan tenda yang dimiliki atau dikelola oleh pedagang kecil, menengah, swadaya masyarakat atau koperasi dengan usaha skala kecil, modal kecil dan dengan proses jual beli barang dagangan melalui tawar menawar.

\section{Syarat - Syarat Pasar Tradisional}

Menurut peraturan Presiden Republik Indonesia nomor 122 tahun 2007 tentang pemabangunan, penataan dan pembinaan pasar tradisional adalah :

1. Aksebilitas, yaitu kemungkinan pencapaian dari dan ke kawasan, dalam kenyataannya ini berwujud jalan dan transportasi atau pengaturan lalu lintas.

2. Kompatibilitas, yaitu keserasian dan keterpaduan antara kawasan yang menjadi lingkungannya.

3. Fleksibilitas, yaitu kemungkinan pertumbuhan fisik atau pemekaran kawasan pasar dikaitkan dengan kondisi fisik lingkungan dan keterpaduan prasarana.

4. Ekologis, yaitu keterpaduan antara tatanan kegiatan alam yang mewadahinya

\section{Eksistensi Pasar Tradisional}

Dibukanya tempat-tempat perbelanjaan modern menimbulkan kegamangan akan nasib pasar tradisional skala kecil dan menengah di wilayah perkotaan. Hilangnya pasar yang telah berpuluh tahun menjadi penghubung perekonomian pedesaan dengan perkotaan dikhawatirkan akan akan mengakibatkan hilangnya lapangan pekerjaan. Dengan hadirnya pasar-pasar modern pemerintah harus tanggap dan membuat peraturanperaturan perundangan dan berharap mampu memberikan solusi bagi permasalahan yang dihadapi pasar tradisional. Akan tetapi juga tidak mematikan hadirnya pasar-pasar modern. Keberadaan pasar tradisional dari satu sisi memang banyak memiliki kekurangan seperti lokasinya yang kadang mengganggu lalu lintas, kumuh, kurang tertata, dan lain-lain. Akan tetapi perlu diingat bahwa pasar tradisional memegang peran yang cukup penting dalam perekonomian, mengingat bahwa sebagian besar masyarakat masih mengandalkan perdagangan melalui pasar tradisional. Sehingga sudah selayaknya pemerintah kota memperhatikan eksistensi pasar tersebut.

Pembenahan terhadap masalah yang muncul dari keberadaan dua pasar tersebut haruslah segera mencari solusi yang tepat. Misalnya saja dengan melarang pembangunan pasar-pasar modern yang letaknya dekat dengan pasar tradisional. Selain itu pemerintah juga memberi tempat atau merelokasi pasar, seperti pasar Klithikan. Penanganan pasar tradisional tersebut haruslah terprogram oleh pemda untuk memberikan proteksi terhadap pasar-pasar tersebut yang semakin tergerus oleh kehadiran tempat pembelanjaan modern. Pembenahan pasar ini tidak semata-mata untuk melindungi pasar tradisional dengan masyarakat awamnya. Akan tetapi juga untuk menarik minat wisatawan baik lokal maupun asing. Hal tersebut merupakan langkah yang cukup bijak mengingat penataan tidak hanya bertujuan untuk menjaga kelangsungan pasar tetapi juga untuk meningkatkan pemasukan perekonomian. Sehingga kebijakan tersebut lebih menguntung-kan banyak pihak.

Akan tetapi untuk pembenahan pasar ini tidak semudah membalikkan telapak tangan. Karena menyangkut tingkat pendidikan masyarakat lapis bawah yang cenderung rendah. Selain itu pola kebiasaan masyarakat juga turut menjadi penghambat penataan pasar. Secara normatif solusi yang tepat untuk 
mengatasi beberapa permasalahan tersebut adalah dengan menyinergikan pasar tradisional dan tempat perbelanjaan modern sebagai satu kesatuan fungsional. Kebijakan-kebijakan pemerintah haruslah bersifat memberikan solusi kepada pasar-pasar tradisional. Karena pasar tradisional merupakan merupakan salah satu pilar ekonomi yang cukup potensial untuk meningkatkan perekonomian. Pasar tersebut mampu memberikan kehidupan bagi perekonomian terutama masyarakat bawah. Pemda juga diuntungkan dengan dijadikannya pasarpasar tradisional menjadi kawasan tujuan wisata. Pemda dapat meraup pajak lebih besar dari pasar-pasar tersebut.

\section{Teori Narasi}

Menurut (Danesi 2011:164), Narasi merupakan teks yang telah dikonstruksikan dengan cara tertentu sehingga merepresentasikan rangkaian peristiwa atau tindakan yang dirasa saling berhubungan satu sama lain secara logis atau memiliki jalinan tersendiri. Rangkaian narasi sendiri dapat berdasarkan fakta, atau fiksi. Dalam menceritakan kisah kehidupan sehari - hari, fiksi sering kali terkait dengan fakta untuk memberikan koherensi dan kredibilitas yang lebih bagi kisah - kisah tersebut. Pakar psikologi menyebutnya sebagai "efek Othello" yakni, kebohongan untuk menekankan kebenaran.

Dalam workshop Pixar Masterclass yang dibawakan Matthew Luhn, untuk membantu pengembangan cerita, terdapat suatu kerangka cerita. Kerangka cerita ini biasa digunakan pada kerangka cerita klasik. Dalam pembuatan cerita, terdapat 3 struktur bercerita, struktur tersebut antara lain:

1. Classical

Struktur yang paling sering digunakan dalam cerita fiksi, khususnya dalam film. Struktur ini telah membuktikan dengan respon emosional dari penonton yang besar di banding struktur lainnya. Struktur cerita klasik fokus dengan perubahan karakter. Karakternya berasal dari sesuatu yang dekat dengan mereka tanpa terpengaruh banyak. Semua pertanyaan dan emosi dijelaskan dalam cerita. Dalam struktur klasik, penekanan terjadi pada konflik eksternal dan tokoh utama pun ikut proaktif dalam cerita. Ceritanya linear dan fakta yang konsisten

2. Minimalis

Bentuk cerita ini tidak memiliki perubahan dalam hidup karakter. Mereka tidak juga mengalami perubahan pada awal dan akhir cerita. Cerita yang disampaikan biasanya memiliki akhir terbuka, klimaks yang belum terselesaikan. Tidak semua pertanyaan dalam cerita dapat terjawab, dan beberapa pertanyaan sengaja tidak dijawab di cerita. Sengaja agar penonton bebas menerjemahkan cerita tersebut. Protagonisnya lebih ke reaktif bukan proaktif. Dan sering kali terdapat lebih dari satu tokoh utama.

3. Anti Structure

Pada bentuk cerita ini, realita saling bertentangan, menggali absurditas sehingga realita tidak mempunyai makna. Tidak ada aturan pasti dalam struktur ini. Hampir sama dengan struktur minimalis, karakter tidak benar-benar berubah. Waktu kejadian biasanya dipecah dan acak. Kebetulan lebihsering terjadi ketimbang adanya sebab-akibat.

Teori Sinematografi

Dalam makalah Donny Trihandono (2013), dalam fotografi atau sinematografi memiliki dasar sebagai berikut:

1. Framing : Kegiatan membatasi adegan/ mengatur kamera sehingga 
mencakup ruang pengelihatan yg diinginkan

2. Angle: Sudut pengambilan gambar

3. Shot size : Cara pengambilan gambar

4. Komposisi : Penyususnan elemen dalam sebuah pengambilan gambarm termasuk warna dan objek. Menurut Gabrielle Moura dalam artikelnya Camera Angles pada website elementofcinema.com, sudut pengambilan gambar dapat memberikan makna yang berbeda dalam setiap penggunaannya. Adapun sudut pengambilan gambar tersebut meliputi:

a. Bird's Eye Level

Sudut ini tampak terlihat benar benar dari atas suatu scene. Biasanya digunakan untuk establishing dan penggunaannya bersamaan dengan extreme long shot.

b. High Angle

Dalam sudut pandang ini, kamera terletak di atas actor, seolah actor tersebut melihat ke arah bawah. Posisi ini memberikan kesan bahwa karakter lemah, takut dan tunduk.

c. Eye Level

Sudut pandang berada sejajar dengan tinggi subyek. Sehingga bila actor melihat kearah kamera, ia tidak akan melihat ke atas atau bawah. Sudut pandang ini biasa digunakan dalam perfilman karena sifatnya natural. Tidak memiliki kesan dramatis. Cocok untuk digunakan dalam film komedi, romantic dan acara berita.

d. Low Angle

Sudut pandang ini diletakkan di bawah mata actor, dan lawan bicara actor tersebut terkesan memandang aktir tersebut lebih tinggi. Sudut pandang seperti ini memberikan kesan dominan, agresif dan berkuasa. e. Dutch Angle

Posisi kamera dimiringkan ke salah satu arah, sehingga garis horizon yang ada tampak miring. Pada sudut ini perubahan garis horizon vertical dan horizontal kearah diagonal dapat menciptakan komposisi yang lebih dinamis. Tak jarang penggunaan sudut seperti ini dimaksudkan untuk memberikan kesan artistik yang bisa digunakan untuk sedikit memberikan kesan bingung.

\section{Mise en Scene}

Istilah Mise en Scene mendeskripsikan fitur utama dari representasi sinematik. Istilah ini diambil dari Bahasa Perancis yang dalam Bahasa inggris berarti "which has been put into the scene or put onstage" (Sikov:2010). Ada 6 komponen dari Mise en scene yaitu setting (set \& props), lighting, costume, hair, make-up dan figure behavior. Berikut penjelasan mengenai tiap komponen dari Mise en scene:

1. Setting (set \& props)

Latar (setting) merupakan tempat atau lokasi dimana suatu adegan dimainkan. Dalam dunia film, setting tidak terbatas interior, seperti tempat tinggal atau tempat kerja, tetapi dapat lebih luas secara harfiah ke dunia baru dari galaksi dan luar alam semesta kita sendiri. Untuk memperkuat suasana setting dalam film diperlukan bantuan property. Properti memberikan definisi lebih lanjut pada setting atau menarik perhatian pada detail dalam adegan yang lebih besar.

2. Lighting

Tata cahaya (lighting) adalah seni pengaturan cahaya dengan mempergunakan peralatan pencahayaan agar kamera mampu melihat obyek dengan jelas, dan menciptakan ilusi 
sehingga penonton mendapatkan kesan adanya jarak, ruang, waktu dan suasana dari suatu kejadian yang dipertunjukkan dalam program televisi.

\section{Costume \& Hair}

Kostum merupakan penggunaan pakaian yang digunakan pada tiap karakter dalam sebuah film. Penggunaan kostum yang tepat berkontribusi dalam dunia film.

4. Make-up

Make-up merupakan sesuatu yang mengacu pada penggunaan tata rias wajah pada tiap karakter. Dalam film, tata rias wajah berkaitan erat dengan kostum. Peran tata rias wajah yaitu menciptakan imajinatif dimensi dalam dunia film (Villarejo:2007).

5. Figure Behavior

Menurut (Villarejo:2007) figure Behavior yang dimaksud dalam mise en scene yaitu mendeskripsikan gerakan, ekspresi atau aksi dari aktor atau figur lainnya (hewan, monster, animasi, droid) dalam sebuah shot yang diberikan.

\section{Wawancara}

Dalam proses pengumpulan data dan juga dengan tujuan validasi hasil penelitian, penulis mewawancarai dua orang ahli dalam bidang sinematografi. Demi mendapatkan sudut pandang yang ber-beda, maka kedua narasumber memiliki konteks dalam lingkungan yang berbeda yakni seni rupa murni dan animator (digital artist) lokal yang cukup terkenal.

1. Tomy Faisal Alim, S.Sn.

Beliau yang akrab dipanggil Tomy merupakan salah satu Perupa Kontemporer terkenal sekaligus menjabat sebagai dosen di 2 Universitas ternama. Hingga kini sedang menekuni kuliah S-2 di Institut Kesenian Jakarta (IKJ) sambil terus merancang untuk melakukan kegiatan pameran seni visual bersama kelompok Jalan Baru dan Himpunan Perupa Bogor (HPB)

2. Antonius, S.Sn.

Beliau adalah penulis sekaligus sutradara dari Animasi Knight Kris berdurasi 106 menit yang pernah tayang di Indonesia tahun 2017 lalu yang diproduksi oleh VIVA Fantasia Animation.

Berdasarkan hasil wawancara dengan kedua narasumber tersebut, didapatkan beberapa kesimpulan yaitu :

1. hal yang terpenting dalam membangun short animation yang baik khususnya dari segi environment design adalah dengan memerhatikan dengan baik mood warna tiap scene, sinematografi dan visual design yang baik.

2. short animation bergaya minimalis memang cukup jarang ditemui, namun tidak langsung memberi kesimpulan bahwa gaya minimalis cenderung tidak disukai oleh masyarakat Indonesia. Semuanya bergantung dari animasi itu sendiri.

Di Indonesia sendiri, masih minimnya pengangkatan tema Pasar Tradisional dalam animasi baik pendek maupun series.

\section{Existing Study}

Studi sinematografi Surat untuk Djakarta Animasi dalam praktiknya seringkali digunakan sebagai media hiburan. Seperti dalam iklan dan industri perfilman dimana animasi digunakan untuk mendukung dan meningkatkan visual dari suatu adegan. Dalam proses penceritaan, animasi menggunakan berbagai media untuk menyampaikan pesan seperti suara, gerakan, warna, dll. Dalam proyek tugas akhir ini, Penulis ingin membuat sebuah animasi yang menyampaikan pesannya melalui kesan yang timbul dari perpaduan antara environment shoot dan background 
music. Khusus untuk sinematografi, dan background music sendiri, penulis terinspirasi dari animasi pendek Surat Untuk Djakarta. Disini yang ditekankan adalah momen yang terjadi mulai dari pagi hingga malam.

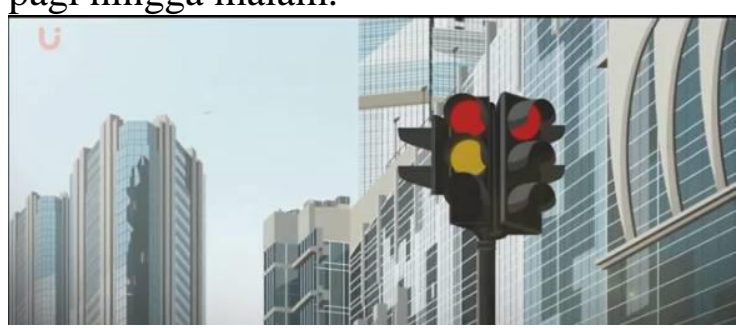

Gambar 2.1. Screenshot Surat untuk Djakarta

\section{Studi cerita Noon}

Alur cerita dan mood warna terinspirasi dari animasi pendek, Noon. Bentuk cerita ini tidak memiliki perubahan dalam hidup karakter. Mereka tidak juga mengalami perubahan pada awal dan akhir cerita. Cerita yang disampaikan biasanya memiliki akhir terbuka, klimaks yang belum terselesaikan. Tidak semua pertanyaan dalam cerita dapat terjawab, dan beberapa pertanyaan sengaja tidak dijawab di cerita. Sengaja agar penonton bebas menerjemahkan cerita tersebut sehingga akan menjadikannya nilai unik khususnya ketika ada hubungan interaksi dengan lingkungannya. Selain itu, akan lebih menarik lagi apabila terdapat bumbu unsur lokal di dalamnya.

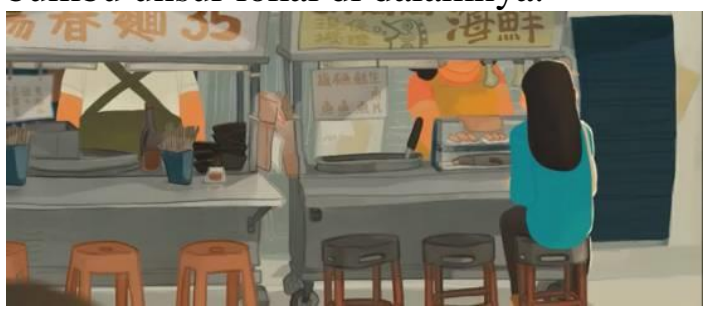

Gambar 2.2. Screenshot Noon

\section{Referensi animasi "No.6"}

Dari data riset yang telah diperoleh akan memberi serangkaian kemungkinan dari beberapa style art yang akan diterapkan ke dalam animasi pendek. Beberapa ada karena kemiripan dalam environment sehingga memberi kemungkinan beberapa referensi ini yang dipilih.

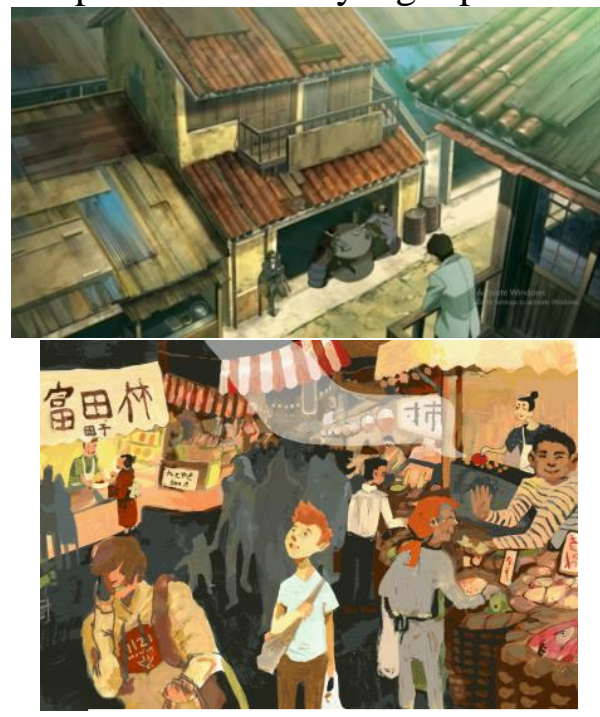

Gambar 2.3. Screenshot No.6

Film ini adalah film animasi 2D yang berjudul "No.6". Referensi dalam aspek mis en scene, sinematografi akan diambil sebagai bahan dalam animasi pendek yang akan dibuat. Dalam hal latar tempat juga terlihat sangat memiliki ciri khas dimana tempat tersebut terkesan kotor. Kombinasi antara angle kamera, perspektif, dan pergerakkan kamera seakan memberi kesan yang dapat memberi rasa emosional dari film.

\section{Studi Warna \\ Warna berperan membantu pe- nyampaian feels dari suatu scene, peng- gunaan warna yang tepat dapat meng- komplemen pesan yang ingin disampai- kan dari suatu animasi. Selain meng- andalkan kekuatan bentuk environment, penulis juga mencoba mengandalkan compositing untuk mem-berikan mood dalam film yang di-produksi, dari warna mute yang penulis pilih, penulis lebih memfokuskan warna soft color untuk memberikan kesan nostalgic.}




\section{METODE PENELITIAN DAN PERANCANGAN}

\section{Metode Riset}

Penulis memanfaatkan metode kualitatif berdasarkan aspek kesesuaian dengan masalah penelitian, tujuan dan tahap penelitian yang cocok. Metode kualitatif ini digunakan untuk meneliti pada kondisi objek yang alamiah, dimana peneliti adalah sebagai instrumen kunci, teknik pengumpulan data dilakukan secara gabungan, analisis data bersifat induktif, dan hasil penelitian kualitatif jauh lebih menekankan makna dari pada generalisasi. Dalam penelitian ini pendekatan yang dilakukan yaitu pendekatan secara observasi langsung menuju ke Pasar. Data yang akan dikumpulkan bukanlah berupa angka atau numerik, melainkan berupa data dari berbagai macam buku, artikel, jurnal yang membahas mengenail tunanetra dan lingkup sekitarnya. Yang menjadi tujuan dari penelitian kualitatif ini adalah untuk menghasilkan deskripsi sesuai catatancatatan yang ada. Data yang telah didapat ini berasal dari berbagai literatur, internet dan interview dengan narasumber yang lebih profesional baik online maupun manual.

\section{Metode Perancangan}

Untuk memproduksi penelitian ini, penulis membuat pipeline dalam pembuatan agar rencana produksi tersusun dengan rapi. Metode produksi animasi ini adalah dengan teknik digital dalam bentuk animasi 2D.

\section{Identifikasi Masalah}

Penulis melakukan observasi dan mendapatkan beberapa masalah-masalah yang akan diidentifikasi:

1. Seiring berkembangnya teknologi, keberadaan pasar tradisional mengalami pergeseran dengan mall, supermarket hingga pasar modern lain.

2. Masih kurangnya minat masyarakat dalam menonton animasi lokal.

Ide cerita

Pencarian ide cerita untuk diangkat ke dalam film animasi berdasarkan dari apa yang dilihat atau didengar, bukan berdasarkan suatu khayalan imajinatif. Serta melakukan pendekatan kreatif terhadap isu yang akan diangkat. Ide cerita terinspirasi dari animasi pendek, Noon. Bentuk cerita ini tidak memiliki perubahan dalam hidup karakter. Mereka tidak juga mengalami perubahan pada awal dan akhir cerita. Cerita yang disampaikan biasanya memiliki akhir terbuka, klimaks yang belum terselesaikan. Tidak semua pertanyaan dalam cerita dapat terjawab, dan beberapa pertanyaan sengaja tidak dijawab di cerita. Sengaja agar penonton bebas menerjemahkan cerita tersebut sehingga akan menjadikannya nilai unik khususnya ketika ada hubungan interaksi dengan lingkungannya. Selain itu, akan lebih menarik lagi apabila terdapat bumbu unsur lokal di dalamnya.

\section{Pengumpulan Data}

Data dikumpulkan dari hasil observasi dan dokumen melalui riset. Melalui tahap riset ini penulis dapat mengumpulkan banyak data baik secara langsung atau tidak langsung. Penggunaan teknik dokumen untuk membantu pengumpulan data terhadap wilayah yang tidak dapat dijangkau oleh penulis.

\section{Penyusunan Cerita}

Dari hasil data yang dikumpulkan, penulis akan menyusun cerita. Untuk membantu pengembangan cerita, terdapat suatu kerangka cerita. Penulis menggunakan kerangka cerita minimalis dimana cerita ini tidak memiliki perubahan dalam hidup karakter, dari awal hingga akhir. 
Desain Karakter

Karakter desain yang diciptakan memiliki pemaknaannya masing masing sehingga dalam pengimplementasiannya dapat sesuai dengan apa yang ingin dikomunikasikan oleh si pembuatnya. Selain itu, environment akan disesuaikan dengan keadaan lokal sesuai keadaan pasar tradisional.

\section{Proses Animasi}

Penulis akan merancang bentuk karakter sesuai dengan konsep setelah data analisa didapatkan. Karakterkarakter ini nantinya akan dimasukan ke dalam film animasi, serta pembuatan setting, perancangan judul, teks dan mood. Dalam film animasi dokumenter ini pengerjaan akan menggunakan ilustrasi manual dengan bantuan software Adobe Photoshop untuk pewarnaan. Dalam proses animasi ini, memuat gerakan-gerakan karakter-karakter serta elemen visual lain yang ada dalam film.

\section{Compositing dan Editing}

Dalam tahap ini, penulis mulai memberikan sentuhan terakhir. Setiap karakter dalam animasi ini juga akan diberi suara agar dapat menyampaikan pesan kepada penontonnya meskipun non-dialog. Gambar yang telah dibuat di compose untuk menjadi sebuah animasi yang bercerita setelah itu dilakukan editing untuk membentuk alur cerita. Proses dilakukan dengan Adobe After Effects dan Adobe Premiere Pro.

Melakukan editing terhadap elemen-elemen suara yang akan dimasukkan ke dalam film untuk mendukung mood dalam film. Melakukan render terakhir untuk finalisasi kesuluruhan film agar dapat ditayangkan.

\section{Ruang Lingkup Penelitian}

Lingkup riset dibatasi pada hal-hal yang dapat ditangani melalui sebuah pendekatan ilmu DKV berupa studi dan eksplorasi visual suasana dan keadaan pasar tradisional di wilayah Jakarta Selatan dan Tangerang dengan lokasi pemilihan pasar di wilayah Pasar Lama, Pasar Lembang dan Pasar Tradisional Plaza Baru. Penulis mengambil lokasi Pasar Lama dengan mengambil visualisasi kulinernya, sedangkan untuk Pasar Lembang dan Tradisional Baru lebih mengambil visualisasi kios grosiran buah dan sayurannya. Penulis akan mencoba membawa suasana masyarakat, tatakrama, sikap, stereotype lalu mencoba berkreasi melalui imajinasi penulis dan menciptakan sebuah karya animasi dengan memanfaatkan latar suasana pasar sebagai acuan. Data akan dikembangkan lebih lanjut menjadi perancangan film animasi pendek 2D.

\section{HASIL DAN PEMBAHASAN}

Dalam penelitian mengenai Final Project ini, penulis melakukan penelitian yang bersifat observasi. Observasi dilakukan dengan melakukan pengamatan, penyelidikan langsung ke tempat pasar. Pasar yang ditargetkan adalah Pasar Lembang, Saraswati dan Pasar Lama di daerah Tangerang. Dari beberapa pengamatan yang dilakukan dibuat beberapa catatan. Dari catatan tersebut dibuat kesimpulan mengenai hal-hal penting yang ada yang kemudian menjadi referensi penting dalam perancangan Final Project nantinya. Observasi yang penulis lakukan bercdasarkan observasi Environment, warna, dan bentuk.

\section{Observasi Pasar}

Dari hasil observasi penulis ke Pasar Lembang, Sarasvati dan Pasar Lama yang merupakan kunjungan pertama penulis. Pada awal masuk ke pasar Sarasvati, Tangerang akan terlihat scene yang penuh dengan keramaian. Dari scene ini, Jika diberi sedikit sentuhan artistik dan mengurangi elemen 
yang tidak dibutuhkan akan memiliki potensi salah satu scene awal animasi pendek.

Banyaknya tenda-tenda tempat penjual memasarkan dagangannya, serta pembeli yang berjalan hilir mudik untuk memilih dan menawar barang yang akan dibelinya. Pada saat memasuki kawasan pasar Sarasvati ini, ada daerah yang terbagi menjadi beberapa bagian diantaranya tempat penjualan buahbuahan, sayuran, ikan, daging dan kuliner. Cukup sulit masuk kesana karena akses jalan tak begitu memadai hanya jalan kecil diantara padatnya. Sinar matahari yang masuk sebagian besar terhalang oleh tenda-tenda namun ada beberapa bagian yang memiliki celah lubang pada tendanya yang memberi pantulan cahaya kecil di beberapa sudut bagian pasar sehingga menimbulkan kesan artistik disini. Dari beberapa ulasan ini memberi beberapa ide plot yang dapat digunakan sebagai referensi visual terhadap ciri khas yang ada di environment tersebut.

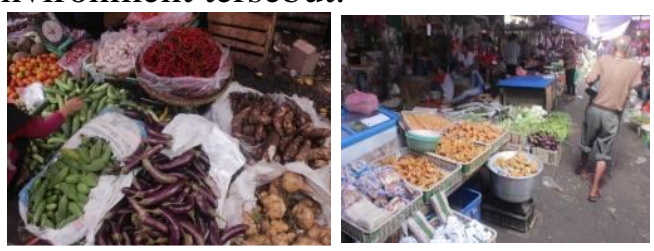

Gambar 2.4. Extreme Shot Sayuran

Warna yang mencolok, bervariasi dan keramaian tempat menjadi poin utama disini. Hal ini dapat menjadi gambaran penting untuk menjadi pertimbangan dalam referensi animasi pendek dari aspek visual. Semakin masuk ke dalam, semakin terlihat padatnya suasana lingkungan pasar tersebut. Terlihat banyak interaksi yang tidak hanya sebagai penjual dan pembeli saja namun juga interaksi antara tiap masyarakat yang mengisi pasar yang seakan memberi warna cerah dari kehidupan di pasar tersebut. Pasar ini tidak sekadar sebagai tempat transaksi jual beli, tetapi juga dapat berkembang menjadi lokasi yang multifungsi dan memiliki fungsi sosial dan budaya sehingga akan sangat menarik untuk menjadikannya bahan dalam animasi pendek nanti. Yang unik dari hal ini adalah meskipun lingkungan terlihat kotor dan kurang tertatanya bahan penjualan, namun pasar ini dipenuhi dengan kehangatan para pengunjungnya dan mereka akan tetap ada selalu mengisi pasar ini dengan kebutuhan sehari-hari mereka mulai dari sebelum terbit fajar hingga petang menjelang malam.

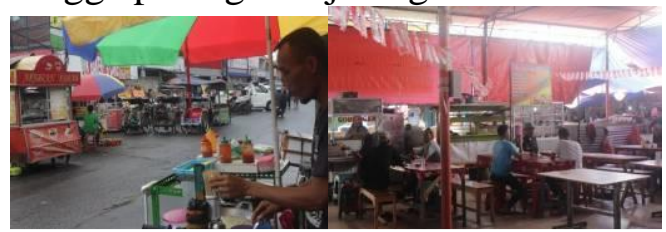

Gambar 2.5. Foto Pedagang Makanan

Suasana tempat makan dimana pengunjung dapat memesan makanan maupun minuman di Pasar. Hal yang unik disini adalah meski dalam lingkungan pasar yang dapat dikatakan kurang nyaman namun masih banyak yang tetap menikmati hidangannya. Inilah yang memberi cita rasa berbeda pada Pasar itu sendiri.

Bagian samping pasar terdapat tempat penjualan burung yang sekaligus juga sebagai tempat perlombaan kicauan burung. Foto kandang burung yang diikutsertakan dalam perlombaan. Dalam angle ini dapat dijadikan sebagai bahan referensi animasi pendek ke depannya. Selain itu, terdapat penampakan bangunan arsitektur ketika berada di depan Pasar Lama. Mungkin pada kali pertamanya berkunjung kita akan merasa heran jika bangunan yang terlihat modern ada di sekitar Pasar yang cenderung lebih ke arah permanen tradisional yang tidak terlalu tertata namun masih nyaman. Suasana di pinggingir jalan raya terlihat seorang pedagang meramu racikan ke dalam makanan dagangannya. 


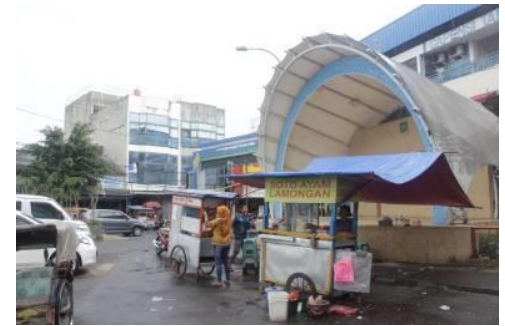

Gambar 2.6. Bangunan vang terlihat lebih

Dari hasil analisa observasi Pasar dapat ditarik kesimpulan sebagai berikut:

1. Faktor yang memengaruhi konsumen memutuskan untuk pergi ke pasar tradisional dikarenakan faktor kebiasaan, jarak tempuhnya serta masyarakat dapat melakukan hutang dan faktor untuk berhutang inilah yang tidak dimiliki oleh pasar modern lain termasuk mall dan supermarket.

2. Beberapa bagian pasar sudah ada yang mengalami revitalisasi dan modernisasi. Contohnya seperti Pasar Lama. Meskipun mengalami modernisasi bukan berarti sisi tradisionalnya sudah menghilang dalam hal ini pemerintah melakukan perbaikan sarana dan pra-sarana dari pasar agar membuat pengunjungnya lebih nyaman. Meskipun ada yang mengalami revitalisasi namun ada beberapa bagian pasar tradisional yang tidak mengikuti perkembangan zaman dan tidak mengikuti tuntutan pasar. Contohnya seperti Pasar Sarasvati.

3. Jenis sayuran yang didagangkan bervariatif dan umumnya memiliki standar kualitas yang tidak jauh berbeda dengan sayuran maupun dagangan di tempat supermarket atau pasar modern lain meskipun tempat menjajakannya dapat dikatakan kurang higienis. Dan hal inilah yang membuat harganya relatif lebih ekonomis dibandingkan dengan kompetitornya.

\section{Penulisan Judul}

Dalam penulisan judul film pendek ini, penulis menggunakan font "SEMRINGAH". Pemilihan font ini dimaksudkan untuk mempertegas kesan luwes dan tradisional dari cerita yang hendak penulis ingin sampaikan. Dalam keilmuan tipografi, huruf san serif melambangkan pribadi dan akrab.

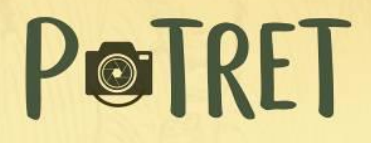

Gambar 2.7. Potret

\section{Perancangan Tokoh Karakter}

Heri

Heri adalah fotografer yang melakukan sesuatu berdasarkan free-will, ia bebas dan tidak terkekang. Ia tidak memiliki hal- hal yang menghalanginya untuk melakukan sesuatu, ia hanya menjadi dirinya sendiri. Penulis menggambarkan Heri mengenakan pakaian yang ringan dan casual, dengan celana panjang coklat.

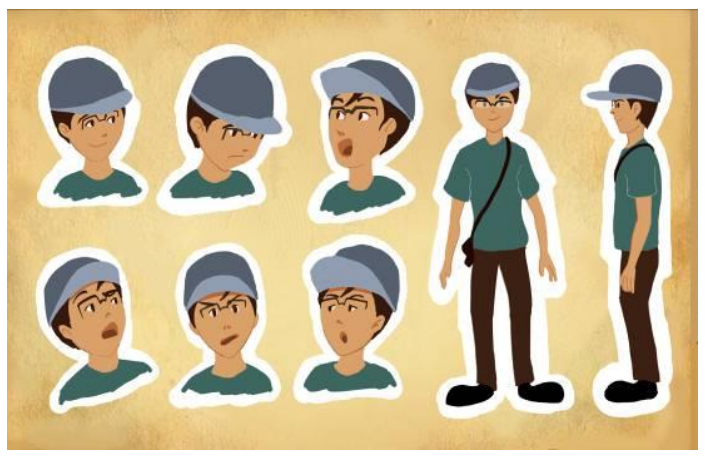

Gambar 2.8. Karakter Desain

\section{Karakter dan Environment}

Karakter dalam animasi pendek ini berkisar pada satu karakter utama, ditambah dengan karakter sampingan yang cukup banyak menunjang dalam plot cerita pendek yang akan dirancang. Berikut data umum karakter dalam animasi pendek yang akan dirancang. 
Heri, Seorang pria paruh baya yang terobsesi fotografi. Dia melihat sesuatu hal yang menurutnya unik dan berbeda dari Pasar Tradisional yang berada di tengah kota, dimana disana banyak dinamika sosio-kultural yang seakan tak terlekang oleh arus globalisasi di era modern ini. Heri mengenakan kacamata dengan kaos casual. Ia mengenakan celana panjang coklat dan sepatu hitam yang dapat dikatakan cukup mencolok saat berada di tempat seperti Pasar Tradisional yang terkesan kumuh. Heri umumnya adalah seorang yang senang akan hal baru berbau petualangan.

Sedangkan untuk perancangan environment yang akan digunakan adalah sebagai berikut:

Tempat Makan.

Suasana tempat makan dimana pengunjung dapat memesan makanan maupun minuman di Pasar. Hal yang unik disini adalah meski dalam lingkungan pasar yang dapat dikatakan kurang nyaman namun masih banyak yang tetap menikmati hidangannya. Inilah yang memberi cita rasa berbeda pada Pasar itu sendiri.

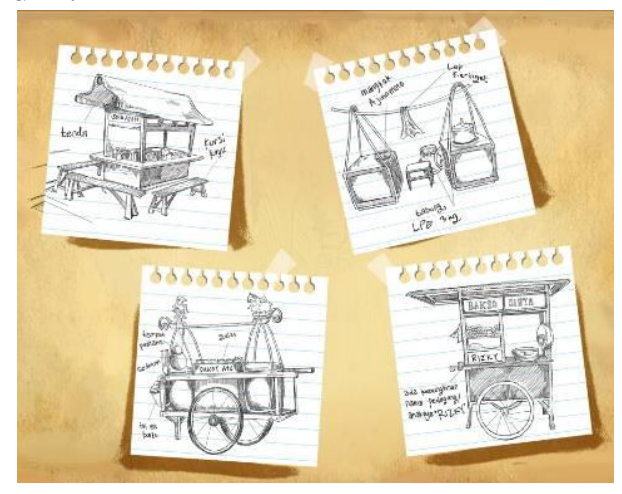

Gambar 2.9. Sketsa Konsep Dagangan

Pasar Tradisional Indoor dan Outdoor

Terlihat banyak interaksi yang tidak hanya sebagai penjual dan pembeli saja namun juga interaksi antara tiap masyarakat yang mengisi pasar yang seakan memberi warna cerah dari kehidupan di pasar tersebut. Pasar ini tidak sekadar sebagai tempat transaksi jual beli, tetapi juga dapat berkembang menjadi lokasi yang multifungsi dan memiliki fungsi sosial dan budaya sehingga akan sangat menarik untuk menjadikannya bahan dalam animasi pendek nanti. Yang unik dari hal ini adalah meskipun lingkungan terlihat kotor dan kurang tertatanya bahan penjualan, namun pasar ini dipenuhi dengan kehangatan para pengunjungnya dan mereka akan tetap ada selalu mengisi pasar ini dengan kebutuhan sehari-hari mereka mulai dari sebelum terbit fajar hingga petang menjelang malam.

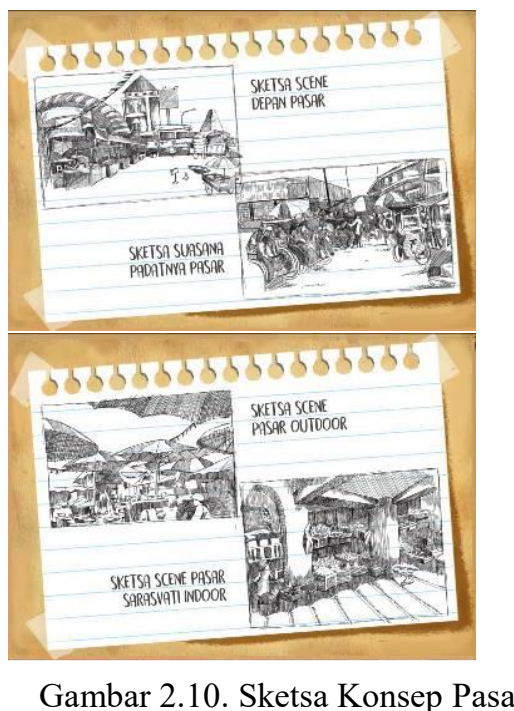

\section{Toko Kelontong}

Toko kecil yang umumnya mudah diakses umum atau bersifat lokal. Banyaknya tenda-tenda tempat penjual memasarkan dagangannya, serta pembeli yang berjalan hilir mudik untuk memilih dan menawar barang yang akan dibelinya. Warna yang mencolok, bervariasi dan keramaian tempat menjadi poin utama disini.

\section{Story Style}

Untuk penceritaannya penulis banyak terinspirasi sendiri dari Short animation Noon. Bentuk cerita ini tidak memiliki perubahan dalam hidup karakter. Mereka tidak juga mengalami 
perubahan pada awal dan akhir cerita. Cerita yang disampaikan biasanya memiliki akhir terbuka, klimaks yang belum terselesaikan. Tidak semua pertanyaan dalam cerita dapat terjawab, dan beberapa pertanyaan sengaja tidak dijawab di cerita. Sengaja agar penonton bebas menerjemahkan cerita tersebut sehingga akan menjadikannya nilai unik khususnya ketika ada hubungan interaksi dengan lingkungannya. Selain itu, akan lebih menarik lagi apabila terdapat bumbu unsur lokal di dalamnya.

Selain itu alur cerita Surat Untuk Djakarta juga penulis ambil sebagai referensi. Kesamaan alur cerita ini membuat penulis semakin yakin untuk mengembangkan pola cerita menjadi cerita yang akan digunakan dalam tugas akhir ini. Pemilihan warna yang menggunakan warna warm spring tone muted. Penggunaan warna ini untuk memberikan kesan cerah, colorful, nostalgia dan tradisional.

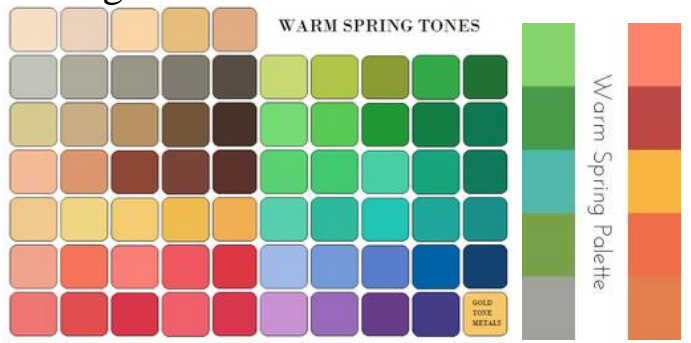

Gambar 2.11. Warm Spring Tone

Selain mengandalkan kekuatan bentuk environment, penulis juga mencoba mengandalkan compositing untuk memberikan mood dalam film yang diproduksi, dari warna mute yang penulis pilih, penulis lebih memfokuskan warna soft color untuk memberikan kesan nostalgic.

\section{Design Concept}

Dalam hal ini, penulis membuat beberapa perancangan visual akhir yang kira-kira ingin dicapai dalam pembuatan animasi pendek. Warna yang dipakai didominasi warna kuning jingga, dengan variasi saturation dan brightness, sehingga mendapatkan feel suasana siang menjelang sore. Adapun design concept dari scene yang ingin dicapai oleh penulis sebagai berikut:
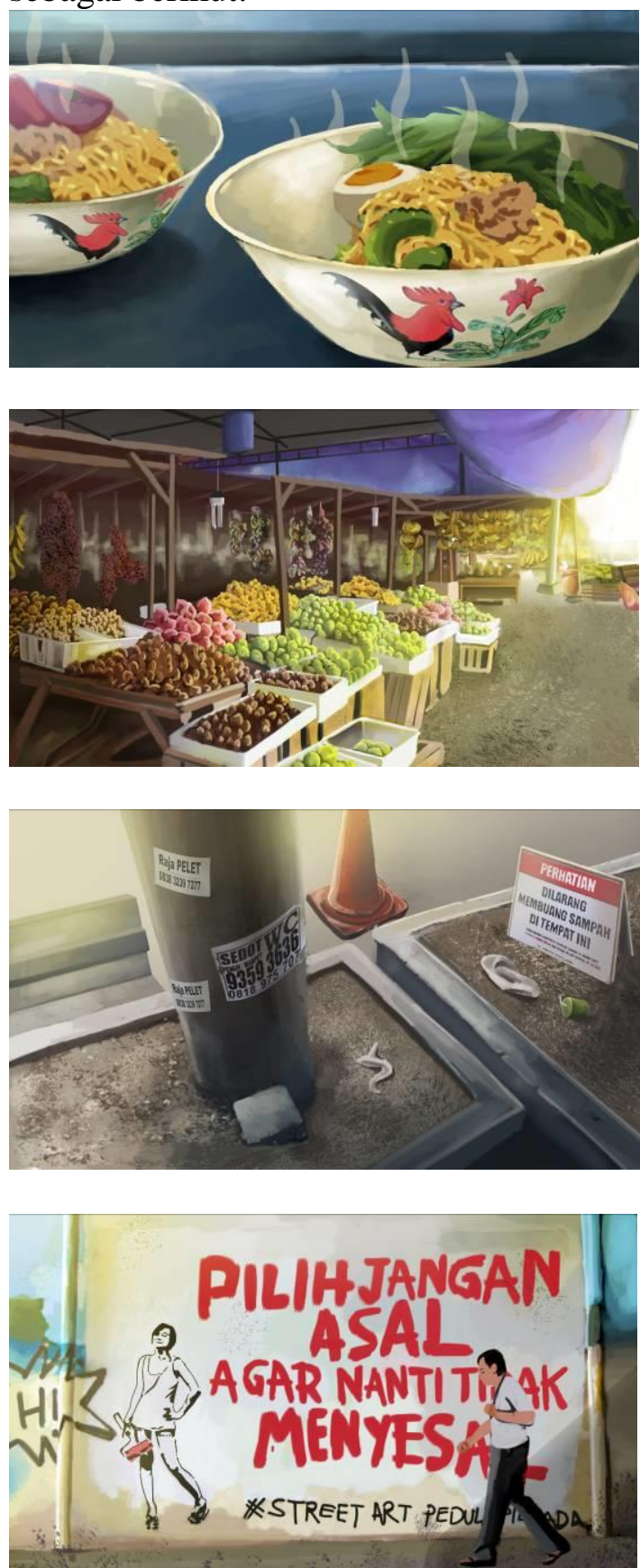

Gambar 2.12. Final Look

\section{SIMPULAN}

Tujuan dari sebuah animasi selain menghibur adalah sebagai media 
komunikasi. Tugas penulis disini adalah sebagai perancang animasi, dalam hal ini penulis menerapkan informasi dan fakta yang ada dan mengubahnya menjadi sebuah pesan dengan bentuk lain yang mudah dikomunikasikan kepada audiens secara visual. Jadi animasi tidak dibuat sedemikian rupa hanya karena imajinasi belaka atau persepsi tiap orang yang berbeda.

Permasalahan sosial atau konflik yang selama ini ada namun kurang mendapat perhatian masyarakat merupakan beberapa alasan penting dalam pembuatan suatu karya. Hal-hal seperti itulah yang mesti dipublikasikan karena selain menyumbang karya, maka karya itu sendiri memiliki tujuan untuk kepentingan umum. Penulis melakukan studi literatur serta wawancara dari sumber yang dapat dipertanggung jawabkan. Oleh karena itulah dibutuhkan adanya riset untuk memenuhi data-data yang dibutuhkan agar tidak asal mempublikasikan data yang tidak valid.

Tema yang penulis angkat adalah Pasar Tradisional, dilatar belakangi oleh keprihatinan penulis mengenai keberadaan Pasar Tradisional yang makin tenggelam sehingga perlu diekspos lebih, stigma masyarakat terhadap Pasar itu sendiri dan masih minimnya pengetahuan masyarakat terhadap keberadaan animasi lokal sehingga tidak banyak masyarakat yang sadar akan beragamnya hal-hal di sekitar kita yang terlihat cukup sepele bisa diekspos menjadi hal di luar dugaan dengan perspektif/sudut pandang yang berbeda.

\section{DAFTAR PUSTAKA}

Bordwell, D. (2006). Film Art and Film Making Part One. New York: The Mac-Graw Hill Company Inc.

Chong, A. (2008). Digital Animation. Singapore: AVA Publishing SA.

Danesi, M. (2011). Pesan, Tanda, dan Makna. Yogyakarta: Jalansutra.

Fichner-Rathus, L. (2007). Foundation of Arts and Design. Boston: Wadsworth Publishing.

Prakosa, G. (2010). Animasi Pengetahuan Dasar Film Animasi Indonesia. Jakarta: FFTV-IKJ dan Yayasan Seni Visual Indonesia.

Sikov, Ed. (2010). Film Studies: An Introduction. New York: Columbia University Press.

Villarejo, A. (2007). Film Studies The Basic. New York: Routledge.

Wright, J.A. (2005). Animation Writing and Development From Script Development To Pitch. Burlington, MA: Focal Press. 